\title{
UPDATE Post-operative rehabilitation and nutrition in
}

\section{osteoarthritis [version 2; peer review: 2 approved with}

\section{reservations]}

\author{
Giuseppe Musumeci ${ }^{1}$, Ali Mobasheri2-4, Francesca Maria Trovato5, \\ Marta Anna Szychlinska1 ${ }^{1}$, Rosa Imbesi ${ }^{1}$, Paola Castrogiovanni ${ }^{1}$
}

\footnotetext{
${ }^{1}$ Department of Biomedical and Biotechnological Sciences, Human Anatomy and Histology Section, School of Medicine, University of Catania, Catania, 95123, Italy

${ }^{2}$ Faculty of Health and Medical Sciences, University of Surrey, Guildford, Surrey, GU2 7XH, UK

${ }^{3}$ Arthritis Research UK Centre for Sport, Exercise and Osteoarthritis, Nottingham University Hospitals, Nottingham, NG7 2UH, UK

${ }^{4}$ Center of Excellence in Genomic Medicine Research (CEGMR), King Fahd Medical Research Center (KFMRC), King AbdulAziz University, Jeddah, 21589, Saudi Arabia

${ }^{5}$ Department of Clinical and Experimental Medicine, Internal Medicine Division, School of Medicine, University of Catania, Catania, 95123, Italy
}

V2 First published: 23 May 2014, 3:116

https://doi.org/10.12688/f1000research.4178.1

Second version: 21 Apr 2015, 3:116

https://doi.org/10.12688/f1000research.4178.2

Latest published: 06 Jan 2016, 3:116

https://doi.org/10.12688/f1000research.4178.3

\section{Abstract}

Osteoarthritis (OA) is a degenerative process involving the progressive loss of articular cartilage, synovial inflammation and structural changes in subchondral bone that lead to loss of synovial joint structural features and functionality of articular cartilage. OA represents one of the most common causes of physical disability in the world. Different OA treatments are usually considered in relation to the stage of the disease. In the early stages, it is possible to recommend physical activity programs that can maintain joint health and keep the patient mobile, as recommended by OA Research Society International (OARSI) and European League Against Rheumatism (EULAR). In the most severe and advanced cases of OA, surgical intervention is necessary. After, in early postoperative stages, it is essential to include a rehabilitation exercise program in order to restore the full function of the involved joint. Physical therapy is crucial for the success of any surgical procedure and can promote recovery of muscle strength, range of motion, coordinated walking, proprioception and mitigate joint pain. Furthermore, after discharge from the hospital, patients should continue the rehabilitation exercise program at home associated to an appropriate diet. In this review, we analyze manuscripts from the most recent literature and provide a balanced and comprehensive overview of the latest developments on the effect of physical exercise on postoperative rehabilitation in OA.

\section{Open Peer Review

$\begin{array}{rrr}\text { Approval Status } & \\ 1 & 2 & 3\end{array}$ \\ version 3 \\ (revision) \\ 06 Jan 2016 \\ version 2 \\ (update) \\ 21 Apr 2015 \\ version 1 \\ 23 May 2014 \\ 1. Ivana Gadjanski iD), Kragujevac \& \\ Metropolitan University Belgrade, \\ Kragujevac, Serbia \\ 2. Carolien H. G Bastiaenen, Maastricht University, Maastricht, The Netherlands \\ 3. Fabio Galbusera, IRCCS Galeazzi Orthopedic Institute, Milan, Italy \\ Any reports and responses or comments on the}


The literature search was conducted using PubMed, Scopus, Web of Science and Google Scholar, using the keywords 'osteoarthritis', 'rehabilitation', 'exercise' and 'nutrition'. The available data suggest that physical exercise is an effective, economical and accessible to everyone practice, and it is one of the most important components of postoperative rehabilitation for OA.

\section{Keywords}

Osteoarthritis, Rehabilitation, Exercise article can be found at the end of the article.

Corresponding author: Giuseppe Musumeci (g.musumeci@unict.it)

Competing interests: No competing interests were disclosed.

Grant information: This study was supported by grants provided by FIR 2014-2016, (cod. 314509), University of Catania, Italy. A. Mobasheri has received wishes to acknowledge funding from the European Union Seventh Framework Programme (FP7/2007-2013, FP7PEOPLE-2013-IEF) under grant agreement numbers 305815 and 625746.

Copyright: ( 2015 Musumeci G et al. This is an open access article distributed under the terms of the Creative Commons Attribution License, which permits unrestricted use, distribution, and reproduction in any medium, provided the original work is properly cited.

How to cite this article: Musumeci G, Mobasheri A, Trovato FM et al. Post-operative rehabilitation and nutrition in osteoarthritis [version 2; peer review: 2 approved with reservations] F1000Research 2015, 3:116 https://doi.org/10.12688/f1000research.4178.2

First published: 23 May 2014, 3:116 https://doi.org/10.12688/f1000research.4178.1 


\section{REVISED Amendments from Version 1}

The aim of this review was to underline the importance of exercise, combined with an appropriate daily diet, in postoperative rehabilitation for osteoarthritis $(\mathrm{OA})$ patients as an effective economical and accessible tool to everyone.

The goal of the postoperative rehabilitation program in $\mathrm{OA}$ is to restore joint function, prevent functional limitations and mitigate the progression of the disease, but is evident that it would surely have a greater efficacy if combined with a nutritional education in order to promote healthy lifestyle. To help readers better understand, we have added two new sections, nutrition section (mediterranean diet in association with $\mathrm{OA}$ ) and materials and methods section, 3 tables and 1 figure. We have refreshed also the references list.

See referee reports

\section{Introduction}

Osteoarthritis (OA) is a degenerative disease of load-bearing synovial joints ${ }^{1-5}$. Knee OA is the most common type of $\mathrm{OA}^{6}$ and represents one of the most common causes of physical disability in the world ${ }^{7-9}$. Deterioration of the articular cartilage is the main problem associated with $\mathrm{OA}$ with consequent chronic pain and functional restriction ${ }^{10}$. OA can be caused by previous traumas (fractures, ligament tears and meniscal injury), wrong kinematics, obesity, genetics and age, which lead to alterations in the joint cartilage $^{2,8,10}$. Traumatic injury to synovial joints is increasingly considered an important risk factor for the development of post-traumatic OA (PTOA). Traumatic injuries sustained during the lifetime of an individual, combined with normal age-related wear and tear, may conspire to facilitate the progression of degenerative joint diseases and may lead to chronic disability. OA is an insidious disease that typically develops gradually over the years with several symptoms including pain, stiffness, limited range of motion (ROM) in the joint and localized swelling. OA pain usually worsens after physical activity ${ }^{3,11-13}$, while stiffness arises after sitting for prolonged periods of time. As OA progresses, symptoms generally become more severe and then pain can become continuous. Generally, OA occurs when the dynamic steady-state between destructive forces and repair mechanisms alters the joint homeostasis ${ }^{7,14}$. For example, the tibiofemoral mechanics and loading patterns, during walking, influence the regional development of the articular cartilage ${ }^{8}$. Alterations in normal gait mechanics due to trauma, acute injury, ligamentous laxity, weight gain and improper footwear can shift the loading patterns to areas of the articular cartilage not well adapted to accept improper loads ${ }^{8}$. If patients do not improve with non-invasive therapies or have excessive pain and loss of mechanical function, OA treatment consists of surgical intervention ${ }^{15,16}$ and subsequent rehabilitation ${ }^{2,17,18,19}$. All patients with hip and knee OA should be informed about the objectives of the treatment and educated to the importance of all the measures that unload the damaged joint (lifestyle changes, regular exercise, weight reduction and other). The initial focus should be on self-help and patient-driven treatments rather than on passive therapies delivered by health professionals. Subsequently, emphasis should be placed on encouraging adherence to the regimen of non-pharmacological therapy ${ }^{20}$, as widely promoted during the last years (Table 1). Recently, the European League Against Rheumatism
Table 1. Physical activity recommendations for patients suffering from osteoarthritis.

\begin{tabular}{|c|c|c|}
\hline Type of activity & Examples & Recommendations \\
\hline $\begin{array}{l}\text { LOW-IMPACT } \\
\text { AEROBICS }\end{array}$ & $\begin{array}{l}\text { - Brisk walking } \\
\text { - Dancing } \\
\text { - Cycling } \\
\text { - Group exercise } \\
\text { - Swimming Gardening } \\
\text { - Water aerobics }\end{array}$ & $\begin{array}{l}2 \text { hours and } 30 \\
\text { minutes moderate- } \\
\text { intensity or } 1 \text { hour } \\
\text { and } 15 \text { minutes } \\
\text { high-intensity. }\end{array}$ \\
\hline $\begin{array}{l}\text { MUSCLE } \\
\text { STRENGTHENING }\end{array}$ & $\begin{array}{l}\text { - Working with } \\
\text { resistance bands } \\
\text { - Weight training } \\
\text { - Calisthenics }\end{array}$ & $\begin{array}{l}2 \text { or more days per } \\
\text { week. }\end{array}$ \\
\hline BALANCE & $\begin{array}{l}\text { - Standing on one foot } \\
\text { - Tai chi }\end{array}$ & 3 days per week. \\
\hline
\end{tabular}

(EULAR) proposed 11 evidence-based recommendations for the non-pharmacological management of people with hip or knee $\mathrm{OA}^{21}$. Moreover, the OA Research Society International (OARSI) proposed other evidence-based recommendations, providing guidance to patients and practitioners on the treatments applicable to all individuals with knee OA, as well as therapies that can be considered according to specific patient needs and preferences ${ }^{22}$. In the present review, we analyze the effects of postoperative rehabilitation exercise program in OA patients treated with surgical procedures. The aim of this review was to underline the importance of exercise combined with an appropriate daily diet in postoperative rehabilitation for OA patients, and to present exercise as an effective and economical accessible to everyone.

\section{Materials and methods}

In this review, we analysed articles from the most recent literature, providing a balanced and comprehensive overview of the most important discoveries on pathogenesis and therapeutic approaches for osteoarthritis in to the context of post-operative rehabilitation and nutrition. Subsequently, the selected articles were divided in "Morphological aspects of osteoarthritis", "First step postoperative rehabilitation in OA", "Second step postoperative rehabilitation in OA" and "Nutrition in postoperative rehabilitation in OA", to provide interested researchers with a detailed and schematic overview of all the recent studies on osteoarthritis. The literature search was conducted from in March 2014 to April 2015 on PubMed, Scopus, Web of Science and Google Scholar using appropriate keywords (osteoarthritis, rehabilitation, exercise and nutrition). Of approximately 160 papers (original articles, systematic and meta-analysis reviews) only 67 have been chosen and considered appropriate for the purpose of the review. The other papers, have not been considered as they resulted outside the scope of the research.

\section{Morphological aspects of osteoarthritis}

Cartilage is the most commonly studied tissue in the joint in the context of OA research. It is a unique load-bearing connective tissue with viscoelastic and compressive properties that are largely due to the presence of extracellular matrix, mainly composed of collagen type II and the proteoglycan aggrecan ${ }^{9,17,18,23}$. OA is a degenerative process involving the progressive loss of structural features and functionality of the articular cartilage caused by an 
imbalance between anabolic and catabolic processes in the cartilage tissue, so that cartilage degradation exceeds reparative processes and OA progresses ${ }^{10,14,24}$. Generally, the surface of healthy hyaline cartilage appears white, shiny, elastic and firm. In contrast, OA cartilage shows a dull and irregular surface with discoloration, softening, and often with increased production of synovial fluid ${ }^{25}$. In advanced OA the cartilage shows signs of rupture; the cartilage surface is rough and broken by fissures and cracks which can reach down to the calcified zone ${ }^{26}$, and chondrocytes are arranged in clusters (especially around fissures) or disappear. The organization of cartilage is widely disordered and replaced by fibro-cartilaginous, scar-like tissue with fibroblast-like cells ${ }^{27}$. As described in detail by several authors, the development of a rheumatoid-like 'pannus' of various extents can overlay the damaged cartilage tissue, ${ }^{28,29}$. The extent of damage to the articular cartilage depends on the joint surface area, which is exposed to different loading patterns and conditions in distinct regions ${ }^{25}$.

\section{First step post-operative rehabilitation in OA}

Postoperative rehabilitation is crucial for the success of any surgical procedure ${ }^{30}$. It has the purpose of recovering muscle strength, range of motion, coordination in walking and mitigation of the pain. The postoperative rehabilitation program usually starts 48 hours after the surgery procedure as a result of the clinical evaluation of each specific case of OA. The rehabilitation is often long because of the time necessary for the cartilage cells to adapt and mature into repair tissue. Cartilage is a slow adapting tissue, indeed it undergoes $75 \%$ adaptation in approximately 2 years. When the rehabilitation period is too short, the cartilage repair might be put under too much stress, causing the repair to fail ${ }^{30}$. The type of postoperative exercise program depends on the injury. Experimental and clinical studies demonstrate that early, controlled mobilization is superior when compared to immobilization for primary treatment of acute musculoskeletal soft-tissue injuries and postoperative management. Early mobilization helps return the patients more quickly to physical activity, reduces persistent swelling, restores stability, restores ROM, and improves patient satisfaction with the rehabilitation outcome ${ }^{31}$.

A postoperative rehabilitation exercise program should be personalized and based on the type of surgical procedure, location, size and depth of the lesion, in order to facilitate the healing process ${ }^{32}$, as well as on the age and medical condition. Arthroscopic procedures, such as chondroplasty or microfracture, may resolve faster than osteochondral autograph transplantation (OATS) or autologous chondrocyte implantation (ACI) that involve larger incisions, requiring a slower exercise rehabilitation program ${ }^{32,33}$. Since immobilization and unloading result in proteoglycan loss in articular cartilage and gradual weakening, controlled weight bearing and ROM are essential to facilitate the healing process and to prevent degeneration $^{24,34,35}$. Furthermore, controlled compression and decompression forces during weight bearing nourish the articular cartilage and induce molecular signals necessary to produce an optimal extracellular matrix ${ }^{34}$. A force platform is a useful tool in the rehabilitation program to perform limited weight-bearing activities facilitate a normal gait pattern and enhance strength, proprioception, and balance $^{32}$. The postoperative rehabilitation exercise program includes performance of motion exercises and muscle strengthening with any ambulatory aids (walker, sticks, forearm crutches), training in postural changes and in the execution of stairs. During rehabilitation, the passive range of motion (PROM) activities, in a limited ROM, are also indicated to nourish the healing articular cartilage and prevent the formation of adhesions ${ }^{36}$. Continuous passive motion (CPM) enhances cartilage healing and long-term outcomes following articular cartilage procedures ${ }^{36}$. As the lesion heals and symptoms decrease, the ROM is modified to allow greater muscle strengthening over a greater range of movement ${ }^{32}$. With surgical procedures, particularly with the OATS and ACI, because of the large incision and extensive soft tissue trauma, arthrofibrosis could take place and rehabilitation can avoid this event ${ }^{32}$. When the surgical procedure has implanted a prosthesis, depending on the type of prosthesis, the use of special machines for the passive flexionextension of the joint is advisable.

Symptoms, such as pain and effusion, could cause the inhibition of the muscles, so electrical muscle stimulation and biofeedback are complementary with the rehabilitation exercise program to promote the active contraction of musculature ${ }^{36}$.

Stretching exercises should be included as the patient progresses to advanced phases of rehabilitation $^{32}$. As the patient returns to functional activities, it is important to increase gradually the amount of stress applied to the treated joint, to provide a stimulus for healing to cartilage tissues without causing damage ${ }^{32}$. The rehabilitation exercise program following surgical procedures for OA is fundamental to the long-term success and functional outcome of patients involved $^{32}$ (Table 2).

\section{Second step post-operative rehabilitation in OA}

Following hospital discharge, the patient should continue the rehabilitation exercise program at home. The physiotherapist will indicate and teach the exercises to be carried out independently, aimed at maintaining a good muscular and articular quality. Patients surgically treated for OA often suffer from pain and have problems during everyday activities, and physical activity could attenuate these deficits ${ }^{37}$. Strengthening exercises, aerobic exercises or both together, show positive effects for both pain and physical function ${ }^{37,38}$. However, data from literature show that the long-term benefits of exercise have no significant effect on pain or physical function after 6 months, except when booster sessions are implemented ${ }^{39}$.

Resistance exercise decreases pain and increases physical function, reducing disability ${ }^{40}$. It includes loads, repetitions, movement speed and frequency of sessions, and often is supported by the use of machines or free weights ${ }^{41}$. Strength, ROM, pain throughout the range of motion and the possibility of patient to have access to the necessary equipment for exercise should be considered for a resistance exercise program ${ }^{41}$. When access to machines is too expensive for the patient, an exercise program should still be performed at home ${ }^{42-44}$. The resistance exercise program should be performed 3 days per week, with $2-3$ sets per exercise at 8-15 repetitions per $\operatorname{set}^{41}$, and loads should vary from high to low ${ }^{44}$. The patient's tolerance should take into account the initial resistance loads and the joint $\mathrm{ROM}^{41}$. The resistance loads or number of sessions per week should increase as the patient acquires strength and confidence ${ }^{41}$. Resistance exercise increases muscle strength ${ }^{42,43}$ and in a period of 2-9 months of progressive exercise, pain could decrease by $42-43 \%{ }^{42,43}$. 
Isokinetic torque can increase further after greater resistance exercise intensity ${ }^{42}$. These data support the idea that improvements in symptoms and function are directly related to exercise intensity and that higher intensity resistance exercise sustains muscle strength and preserves functionality ${ }^{41}$.

Aerobic exercise includes several activities such as walking, cycling or the use of a seated stepper machine. It has beneficial effects on joint mobility and pain, and it improves the functional status of their general mobility and respiratory capacity ${ }^{30,45}$. Although modality and dosage are currently not well defined, aerobic exercise program should take into account age, mobility, co-morbidities and preferences $^{30}$. The exercise bike is a helpful tool for exercising at home. Aquatic exercise seems not to have effects on walking ability or joint $\mathrm{ROM}^{46}$, so it should be considered as an optional activity for exercise program $^{30,46}$. Land-based exercise and aerobic exercise show higher beneficial effects for pain and function compared with aquatic exercise and strengthening exercise ${ }^{47}$. A combination of both aerobic training and strengthening exercise could be an optimal choice to decrease impairments ${ }^{48}$. The beneficial effects of exercise programs are mostly related to the adherence and constancy of patients to the program and the number of sessions, while variations in the delivery, content and dosage do not influence the outcome ${ }^{37}$. Data from literature show that exercise programs have short-term benefits in reducing pain and improving physical function, but they do not persist in the long term without adherence to the program ${ }^{37,39,45}$. Strategies to increase long-term adherence to exercise are necessary to maximize the benefits of exercise program ${ }^{37}$. Self-efficacy is also associated with higher adherence and better outcomes ${ }^{45}$. Finally, the exercise program should be combined with education and behavioral strategies to promote a positive lifestyle change and increase physical activities ${ }^{30}$ (Table 3$)$.

\section{Nutrition in postoperative rehabilitation in OA}

As mentioned above, cartilage is a connective tissue with viscoelastic and compressive properties, largely due to the extracellular matrix, mainly composed of collagen type II and the proteoglycan aggrecan ${ }^{9,17,18,23}$. In OA, a progressive loss of structural features occurs because of an imbalance between anabolic and catabolic processes in the cartilage tissue $e^{10,14,24}$. Therefore, one of the goals of OA postoperative rehabilitation, in addition to the restoration of joint function, is the metabolic homeostasis of cartilage tissue, also obtainable through an appropriate diet. The exercise program in OA postoperative rehabilitation would surely have a greater efficacy if

Table 2. First step postoperative rehabilitation in OA. Schematic representation of primary rehabilitation activities that should be included in post-operative rehabilitation program soon after the surgery.

\begin{tabular}{|c|c|c|}
\hline PHASE & TYPE OF ACTIVITY & EFFECTS \\
\hline \multirow[t]{7}{*}{ FIRST STEP } & CONTROLLED WEIGHT BEARING & $\begin{array}{l}\text { Nourishes the articular cartilage and provides molecular } \\
\text { signals necessary to produce an optimal extracellular matrix. }\end{array}$ \\
\hline & RANGE OF MOTION (ROM) & Facilitates healing process and prevents degeneration. \\
\hline & FORCE PLATFORM & $\begin{array}{l}\text { Facilitates a normal gait pattern and enhances strength, } \\
\text { proprioception, and balance. }\end{array}$ \\
\hline & PASSIVE RANGE OF MOTION (PROM) & $\begin{array}{l}\text { Nourishes the healing articular cartilage and prevents the } \\
\text { formation of adhesions. }\end{array}$ \\
\hline & CONTINUOUS PASSIVE MOTION (CPM) & Enhances cartilage healing and long-term outcomes. \\
\hline & $\begin{array}{l}\text { ELECTRICAL MUSCLE STIMULATION AND } \\
\text { BIOFEEDBACK }\end{array}$ & Promotes the active contraction of musculature. \\
\hline & $\begin{array}{l}\text { STRETCHING EXERCISES (in advanced } \\
\text { phases of rehabilitation) }\end{array}$ & $\begin{array}{l}\text { Increases the amount of stress applied to the joint and } \\
\text { provides a stimulus for cartilage tissue healing. }\end{array}$ \\
\hline $\begin{array}{l}{ }^{*} \text { In case of } \\
\text { prosthesis }\end{array}$ & $\begin{array}{l}\text { PASSIVE FLEXION-EXTENSION (with use of } \\
\text { special machines) }\end{array}$ & Facilitates healing process. \\
\hline
\end{tabular}

Table 3. Second step postoperative rehabilitation in OA. Schematic representation of rehabilitation activities that the patients, once discharged from hospital, should keep on at home.

\begin{tabular}{|c|c|c|}
\hline PHASE & TYPE OF ACTIVITY & EFFECTS \\
\hline \multirow[t]{4}{*}{$\begin{array}{l}\text { SECOND } \\
\text { STEP }\end{array}$} & STRETCHING EXERCISES & $\begin{array}{l}\text { Increases gradually the amount of stress applied to the treated } \\
\text { joint, provides a stimulus for healing to cartilage tissues without } \\
\text { causing damage and has positive effects for both pain and physical } \\
\text { function. }\end{array}$ \\
\hline & RESISTANCE EXERCISE & Decreases pain, increases physical function and reduces disability. \\
\hline & AEROBIC EXERCISE & $\begin{array}{l}\text { Has beneficial effects on joint mobility and pain, and improves } \\
\text { functional status and respiratory capacity. }\end{array}$ \\
\hline & NUTRITIONAL EDUCATION & $\begin{array}{l}\text { Improves metabolic homeostasis of cartilage tissue and determines } \\
\text { protection against chronicity of the disease. }\end{array}$ \\
\hline
\end{tabular}


combined with a nutritional education in order to promote a healthier lifestyle. There are numerous foods containing natural antiinflammatory compounds, which are able to reduce some important symptoms of OA, such as pain. These foods are known as natural painkillers and some of them are illustrated in Figure 1.

The Mediterranean Diet (Med Diet) is the traditional dietary pattern of the Mediterranean areas in the early $1960 \mathrm{~s}^{49}$. Olive oil (OO) is the principal source of fat of Med Diet. It is extracted from Olea europaea fruits and is rich in monounsaturated fatty acids (MUFAs). The beneficial effects of $\mathrm{OO}$ are ascribed to its phytochemicals such as phenolic compounds, tocopherol and carotenoids, that have antimicrobial, antioxidant and anti-inflammatory properties $^{50}$. Some epidemiological studies reported an association between consumption of diets rich in polyphenols and protection against chronic diseases ${ }^{51}$, but few studies investigated the effects on cartilage tissue of such compounds that seem to have a potential protective role ${ }^{52}$. The phenolic compounds present in OO may interact with the inflammatory cascade preventing cellular damage thank to their antioxidant action. In rheumatoid arthritis patients the dietary supplementation with OO improves joint pain and morning stiffness ${ }^{53}$. Both leaves and fruit of the olive plant are rich in beneficial polyphenols $\mathrm{s}^{54}$, among which the most bioactive are oleuropein and hydroxytyrosol ${ }^{52}$. Oleuropein is a secoiridoid and represents the most important microconstituent of virgin $\mathrm{OO}$ for its health implications. It has high antioxidant activity in vitro, and its hydrolysis product, oleuropein aglycone, ameliorates resistance to the development of arthritis ${ }^{55}$. Indeed oleuropein reduces the release of proinflammatory cytokines and leukocytes infiltration in the joints affected by collagen induced arthritis, thus reducing the progression of chronic joint inflammation ${ }^{55}$. Moreover, when administered after the clinical onset of arthritis, oleuropein reduces swelling and the other clinical manifestations, as well as the histological severity of the disease ${ }^{55}$. This compound reduced the bone loss and improved inflammation, showing a bone sparing effect, in an animal model of senile osteoporosis ${ }^{56}$.

Another important phenolic compound is oleocanthal (OLC) that shows anti-inflammatory and neuroprotective properties ${ }^{57}$. OLC inhibits the cyclooxygenase enzymes in the pathway of prostaglandin biosynthesis in a more potent manner than ibuprofen ${ }^{58}$. Rutin (quercetin-3-O-rutinoside) is a flavonoid ubiquitously found in plants. Quercetin, the circulating aglycone form of rutin, has the ability to scavenge free radicals ${ }^{59,60}$ and the association with oleuropein induces interesting metabolic and structural effects on OA cartilage and synovium, supporting their use in human trials ${ }^{52}$. The fruits of Elaeagnus angustifolia is similar to those of Olea europaea, and although belonging to another botanical family, possesses the same anti-inflammatory potential and was showed to be active in female arthritis patients ${ }^{61}$.

Given its known anti-inflammatory properties, we have recently studied the possible benefits of extra-virgin $\mathrm{OO}$, in association with physical activity on joint disease, in order to evaluate the inflammation and the expression of lubricin in articular cartilage after injury and the consequent occurrence of $\mathrm{OA}^{16}$. In our study, we highlighted that Med Diet and extravirgin OO consumption may

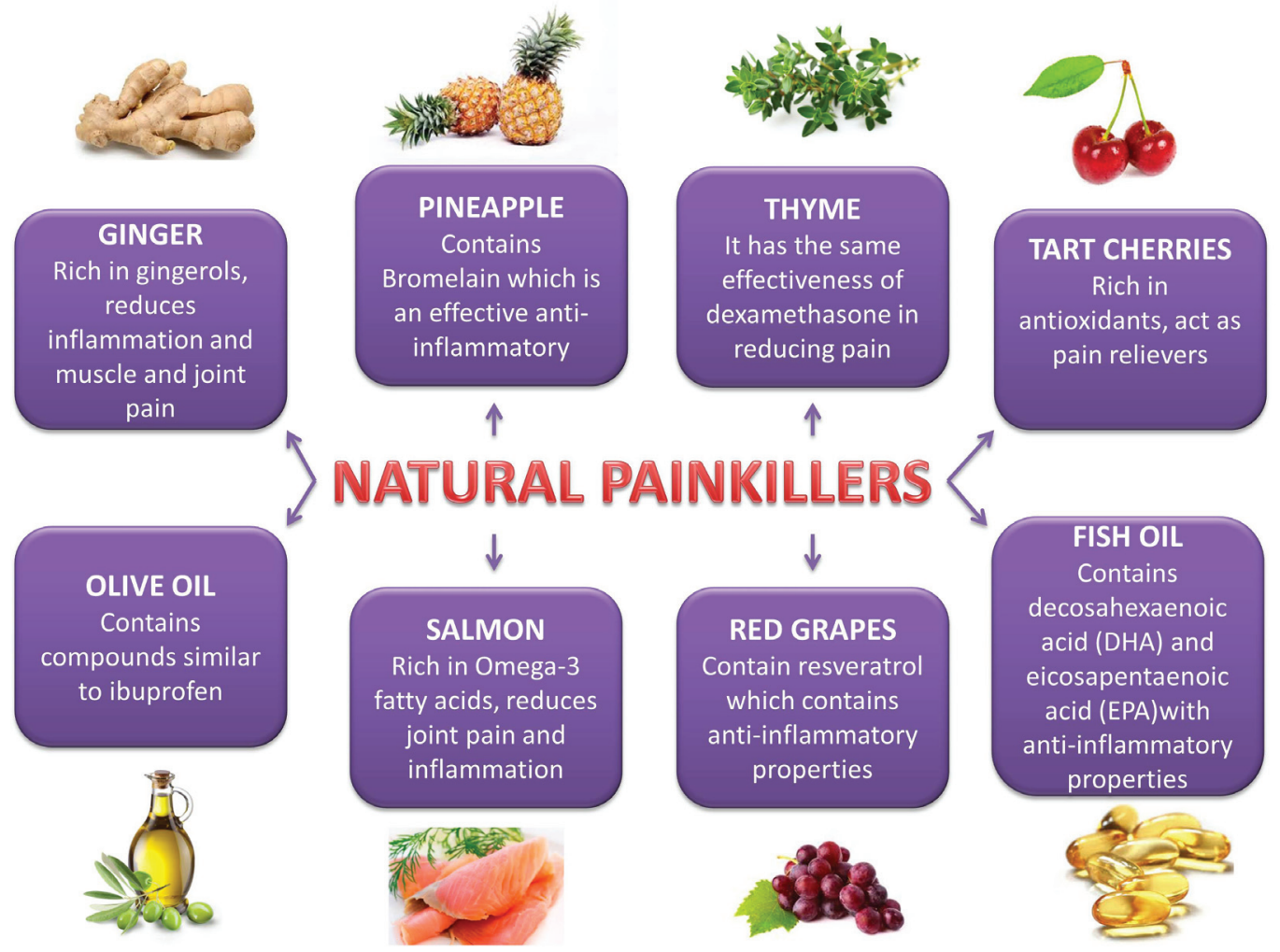

Figure 1. Foods containing compounds with anti-inflammatory and analgesic properties, that may help ease the symptoms of osteoarthritis as well as improve the overall health of patients. 
help attenuate and resolve inflammation in articular cartilage after injury, preventing $\mathrm{OA}^{16}$.

Moreover, deficiencies of vitamins $\mathrm{D}^{62,63}$ and $\mathrm{K}^{64}$ increase the risk of development and progression of OA. A recent controlled trial on arthritis patients comparing the exercise and the nutritional interventions, according to the MyPyramid and MyPlate approaches ${ }^{65}$, showed an improvement also in the nutritional program group, probably due to the weight loss and the increase of motivation to leisure time physical activity ${ }^{66}$. Indeed, lowering the fat content typical of the Western diet increases daily physical activity and resting energy expenditure, affecting also the mood, in particular anger and hostility ${ }^{67}$. Thus, a high consumption of saturated fats might reduce the motivation for physical activity leading to the individual's propensity for weight gain, which is detrimental especially in patients affected by OA. Therefore, a healthy diet combined to a rehabilitation exercise program could improve the quality of life and the mood of post-surgery patients.

\section{Conclusions}

The articular joint is a highly complex 'organ system' that requires regular maintenance. The immobilization of the joints results in a number of negative physiologic consequences. Severity, mobility, pain, stiffness and radiographic progression may be partly mediated by the level of chronic inflammation in OA patients. In the most severe cases of OA, surgical intervention is necessary. It is essential to combine a postoperative rehabilitation exercise program with surgical interventions in order to restore full function of the involved joint. This is crucial for the success of any articular cartilage surgery procedure, and has the purpose to improve muscle strength, ROM, coordination in walking and mitigate of the pain. After hospital discharge, patients should continue the rehabilitation exercise program at home with strengthening exercises, aerobic exercises or both, combined together with a correct diet, so that positive benefits may be gained in terms of pain control and quality of life. Furthermore, regular physical activity combined with a healthy diet improves physical function, muscular strength and endurance, reduces some OA symptoms and leads to psychological and mood benefits. The goal of the postoperative rehabilitation program in $\mathrm{OA}$ is to restore joint function, prevent functional limitations and mitigate the progression of the disease, but it is evident that it would surely have a greater efficacy if combined with a nutritional education in order to promote a healthy lifestyle.

\section{Author contributions}

All authors have made substantial intellectual contributions to the conception and design of the study. GM conceived the study design and supervised, wrote and structured the review. AM reviewed and edited the paper. FMT and PC researched the area and identified papers, wrote and structured the review. MAS and RI structured the paper and literature search. All authors have approved the final version submitted.

\section{Competing interests}

No competing interests were disclosed.

\section{Grant information}

This study was supported by grants provided by FIR 2014-2016, (cod. 314509), University of Catania, Italy. A. Mobasheri has received wishes to acknowledge funding from the European Union Seventh Framework Programme (FP7/2007-2013, FP7-PEOPLE2013-IEF) under grant agreement numbers 305815 and 625746.

\section{Acknowledgements}

The authors would like to thank Prof. Iain Halliday for commenting and making corrections to the paper.
1. Schroeppel JP, Crist JD, Anderson HC, et al.: Molecular regulation of articular chondrocyte function and its significance in osteoarthritis. Histol Histopathol. 2011; 26(3): 377-394 PubMed Abstract

2. Sinusas K: Osteoarthritis: diagnosis and treatment. Am Fam Physician. 2012; 85(1): 49-56. PubMed Abstract

3. Musumeci G, Castrogiovanni P, Leonardi R, et al:: New perspectives for articular cartilage repair treatment through tissue engineering: A contemporary review. World J Orthop. 2014; 5(2): 80-88. PubMed Abstract | Free Full Text

4. Musumeci G, Leonardi R, Carnazza ML, et al:: Aquaporin 1 (AQP1) expression in experimentally induced osteoarthritic knee menisci: an in vivo and in vitro study. Tissue Cell. 2013; 45(2): 145-152. PubMed Abstract | Publisher Full Text

5. Pichler $\mathrm{K}$, Loreto $\mathrm{C}$, Leonardi $\mathrm{R}$, et al.: RANKL is downregulated in bone cells by physical activity (treadmill and vibration stimulation training) in rat with glucocorticoid-induced osteoporosis. Histol Histopathol. 2013; 28(9): with glucocort $1185-1196$. PubMed Abstract

6. Musumeci G, Loreto C, Carnazza ML, et al.: Characterization of apoptosis in articular cartilage derived from the knee joints of patients with osteoarthritis. Knee Surg Sports Traumatol Arthrosc. 2011; 19(2): 307-313. PubMed Abstract | Publisher Full Text

7. Egloff $\mathrm{C}$, Hügle $\mathrm{T}$, Valderrabano V: Biomechanics and pathomechanisms of osteoarthritis. Swiss Med Wkly. 2012; 142: w13583.

PubMed Abstract | Publisher Full Text

8. Vincent KR, Conrad BP, Fregly BJ, et al.: The pathophysiology of osteoarthritis: a mechanical perspective on the knee joint. PM R. 2012; 4(5 Suppl): S3-S9. PubMed Abstract | Publisher Full Text | Free Full Text

9. Musumeci G, Castrogiovanni P, Trovato FM, et al.: Microscopic and macroscopic anatomical features in healthy and osteoarthritic knee cartilage. OA Anatomy. 2013; 1(3): 30. Reference Source

10. Lorenz H, Richter W: Osteoarthritis: cellular and molecular changes in degenerating cartilage. Prog Histochem Cytochem. 2006; 40(3): 135-163. PubMed Abstract | Publisher Full Text

11. Musumeci G, Loreto C, Carnazza ML, et al.: Lubricin is expressed in chondrocytes derived from osteoarthritic cartilage encapsulated in poly (ethylene glycol) diacrylate scaffold. Eur J Histochem. 2011; 55(3): e31. PubMed Abstract | Publisher Full Text | Free Full Text

12. Musumeci G, Loreto $\mathrm{C}$, Carnazza ML, et al.: OA cartilage derived chondrocytes encapsulated in poly(ethylene glycol) diacrylate (PEGDA) for the evaluation of cartilage restoration and apoptosis in an in vitro model. Histol Histopathol. 2011; 26(10): 1265-1278. PubMed Abstract

13. Musumeci G, Carnazza ML, Loreto $C$, et al:: $\beta$-defensin-4 (HBD-4) is expressed in chondrocytes derived from normal and osteoarthritic cartilage encapsulated in PEGDA scaffold. Acta Histochem. 2012; 114(8): 805-812. PubMed Abstract | Publisher Full Text 
14. Kouri JB, Lavalle C: Do chondrocytes undergo "activation" and "transdifferentiation" during the pathogenesis of osteoarthritis? A review of the ultrastructural and immunohistochemical evidence. Histol Histopathol. 2006; 21(7): 793-802.

PubMed Abstract

15. Musumeci G, Loreto C, Leonardi R, et al:: The effects of physical activity on apoptosis and lubricin expression in articular cartilage in rats with glucocorticoid-induced osteoporosis. J Bone Miner Metab. 2013; 31(3): 274-84. PubMed Abstract | Publisher Full Text

16. Musumeci G, Trovato FM, Pichler K, et al:: Extra-virgin olive oil diet and mild physical activity prevent cartilage degeneration in an osteoarthritis model: an in vivo and in vitro study on lubricin expression. J Nutr Biochem. 2013; 24(12): 2064-2075.

PubMed Abstract | Publisher Full Text

17. Musumeci G, Loreto C, Castorina S, et al:: Current concepts in the treatment of cartilage damage. A review. Ital J Anat Embryol. 2013; 118(2): 189-203. PubMed Abstract | Publisher Full Text

18. Musumeci G, Loreto C, Castorina S, et al:: New perspectives in the treatment of cartilage damage. Poly(ethylene glycol) diacrylate (PEGDA) scaffold. A review. Ital J Anat Embryol. 2013; 118(2): 204-210.

PubMed Abstract | Publisher Full Text

19. Musumeci G, Loreto C, Imbesi R, et al.: Advantages of exercise in rehabilitation, treatment and prevention of altered morphological features in knee osteoarthritis. A narrative review. Histol Histopathol. 2014; 29(6): 707-719. PubMed Abstract

20. Zhang W, Moskowitz RW, Nuki G, et al:: OARSI recommendations for the management of hip and knee osteoarthritis, part I: critical appraisal of existing treatment guidelines and systematic review of current research evidence. Osteoarthritis Cartilage. 2007; 15(9): 981-1000.

PubMed Abstract | Publisher Full Text

21. Fernandes L, Hagen KB, Bijlsma JW, et al:: European League Against Rheumatism (EULAR). EULAR recommendations for the non-pharmacologica core management of hip and knee osteoarthritis. Ann Rheum Dis. 2013; 72(7): 1125-35.

PubMed Abstract | Publisher Full Text

22. McAlindon TE, Bannuru RR, Sullivan MC, et al:: OARSI guidelines for the nonsurgical management of knee osteoarthritis. Osteoarthritis Cartilage. 2014 22(3): 363-88.

PubMed Abstract | Publisher Full Tex

23. Musumeci G, Castrogiovanni $\mathrm{P}$, Mazzone V, et al:: Histochemistry as a unique approach for investigating normal and osteoarthritic cartilage. Eur $J$ Histochem. 2014; 58(2): 2371.

PubMed Abstract | Publisher Full Text | Free Full Text

24. Lahm A, Kasch R, Mrosek E, et al:: Semiquantitative analysis of ECM molecules in the different cartilage layers in early and advanced osteoarthritis of the knee joint. Histol Histopathol. 2012; 27(5): 609-615. PubMed Abstract

25. Ruan MZ, Patel RM, Dawson BC, et al:: Pain, motor and gait assessment of murine osteoarthritis in a cruciate ligament transection model. Osteoarthritis Cartilage. 2013; 21(9): 1355-1364.

PubMed Abstract | Publisher Full Text | Free Full Text

26. Veje K, Hyllested-Winge لJ Ostergaard K. Topographic and zonal distribution of tenascin in human articular cartilage from femoral heads: normal versus mild and severe osteoarthritis. Osteoarthritis Cartilage. 2003; 11(3): 217-27. PubMed Abstract | Publisher Full Tex

27. Miosge N, Hartmann M, Maelicke C, et al:: Expression of collagen type I and type II in consecutive stages of human osteoarthritis. Histochem Cell Biol. 2004; 122(3): 229-236.

PubMed Abstract | Publisher Full Text

28. Shibakawa A, Aoki H, Masuko-Hongo K, et al:: Presence of pannus-like tissue on osteoarthritic cartilage and its histological character. Osteoarthritis Cartilage. 2003: 11(2): 133-140.

PubMed Abstract | Publisher Full Tex

29. John T, Stahel PF, Morgan SJ, et al:: Impact of the complement cascade on posttraumatic cartilage inflammation and degradation. Histol Histopathol. 2007; 22(7): 781-790.

PubMed Abstract

30. Bennell KL, Hinman RS: A review of the clinical evidence for exercise in osteoarthritis of the hip and knee. J Sci Med Sport. 2011; 14(1): 4-9. PubMed Abstract | Publisher Full Tex

31. Musumeci G, Trovato FM, Imbesi R, et al.: Effects of dietary extra-virgin olive oil on oxidative stress resulting from exhaustive exercise in rat skeletal muscle: $A$ morphological study. Acta Histochem. 2014; 116(1): 61-69. PubMed Abstract | Publisher Full Text

32. Reinold MM, Wilk KE, Macrina LC, et al:: Current concepts in the rehabilitation following articular cartilage repair procedures in the knee. $J$ Orthop Sports Phys Ther. 2006; 36(10): 774-794. PubMed Abstract | Publisher Full Text

33. Mobasheri A, Csaki C, Clutterbuck AL, et al.: Mesenchymal stem cells in connective tissue engineering and regenerative medicine: applications in cartilage repair and osteoarthritis therapy. Histol Histopathol. 2009; 24(3): 347-366.

PubMed Abstract
34. Vanwanseele B, Lucchinetti E, Stussi E: The effects of immobilization on the characteristics of articular cartilage: current concepts and future directions. Osteoarthritis Cartilage. 2002; 10(5): 408-419.

PubMed Abstract | Publisher Full Text

35. Waldman SD, Spiteri CG, Grynpas MD, et al.: Effect of biomechanical conditioning on cartilaginous tissue formation in vitro. J Bone Joint Surg Am. 2003; 85-A(Suppl 2): 101-105.

PubMed Abstract

36. Tok F, Aydemir K, Peker F, et al:: The effects of electrical stimulation combined with continuous passive motion versus isometric exercise on symptoms, functional capacity, quality of life and balance in knee osteoarthritis: randomized clinical trial. Rheumatol Int. 2011; 31(2): 177-181.

PubMed Abstract | Publisher Full Tex

37. Lin CW, Taylor D, Bierma-Zeinstra SM, et al:: Exercise for osteoarthritis of the knee. Phys Ther. 2010; 90(6): 839-842. PubMed Abstract | Publisher Full Tex

38. Fransen M, McConnell S: Exercise for osteoarthritis of the knee. Cochrane Database Syst Rev. 2008; (4): CD004376. PubMed Abstract | Publisher Full Text

39. Pisters MF, Veenhof $\mathrm{C}$, van Meeteren NL, et al:: Long-term effectiveness of exercise therapy in patients with osteoarthritis of the hip or knee: a systematic review. Arthritis Rheum. 2007; 57(7): 1245-1253. PubMed Abstract | Publisher Full Text

40. Lange AK, Vanwanseele B, Fiatarone Singh MA: Strength training for treatment of osteoarthritis of the knee: A systematic review. Arthritis Rheum. 2008; 59(10): $1488-1494$

PubMed Abstract | Publisher Full Text

41. Vincent KR, Vincent HK: Resistance exercise for knee osteoarthritis. $P M R$. 2012; 4(5 Suppl): S45-S52.

PubMed Abstract | Publisher Full Text | Free Full Text

42. Jan MH, Lin JJ, Liau JJ, et al.: Investigation of clinical effects of high- and low-resistance training for patients with knee osteoarthritis: A randomized controlled trial. Phys Ther. 2008; 88(4): 427-436.

PubMed Abstract | Publisher Full Text

43. Farr JN, Going SB, McKnight PE, et al:: Progressive resistance training improves overall physical activity levels in patients with early osteoarthritis of the knee: a randomized controlled trial. Phys Ther. 2010; 90(3): 356-366. PubMed Abstract | Publisher Full Text | Free Full Text

44. Foroughi N, Smith RM, Lange AK, et al:: Lower limb muscle strengthening does not change frontal plane moments in women with knee osteoarthritis: A randomized controlled trial. Clin Biomech (Bristol, Avon). 2011; 26(2): 167-174. PubMed Abstract | Publisher Full Text

45. Mazieres B, Thevenon A, Coudeyre E, et al:: Adherence to and results of physica therapy programs in patients with hip or knee osteoarthritis. Development of French clinical practice guidelines. Joint Bone Spine. 2008; 75(5): 589-596. PubMed Abstract | Publisher Full Text

46. Bartels EM, Lund $\mathrm{H}$, Hagen KB, et al:: Aquatic exercise for the treatment of knee and hip osteoarthritis. Cochrane Database Syst Rev. 2007; (4): CD005523. PubMed Abstract | Publisher Full Text

47. Zhang W, Nuki G, Moskowitz RW, et al:: OARSI recommendations for the management of hip and knee osteoarthritis: part III. Changes in evidence following systematic cumulative update of research published through January 2009. Osteoarthritis Cartilage. 2010; 18(4): 476-499. PubMed Abstract| Publisher Full Text

48. Roddy E, Zhang W, Doherty M, et al.: Evidence-based recommendations for th role of exercise in the management of osteoarthritis of the hip or knee--the MOVE consensus. Rheumatology (Oxford). 2005; 44(1): 67-73.

PubMed Abstract | Publisher Full Text

49. Willett WC, Sacks F, Trichopoulou A, et al.: Mediterranean diet pyramid: a cultural model for healthy eating. Am J Clin Nutr. 1995; 61(6 Suppl): 1402S-1406S. PubMed Abstract

50. Cicerale S, Lucas LJ, Keast RS: Antimicrobial, antioxidant and anti-inflammatory phenolic activities in extra virgin olive oil. Curr Opin Biotechnol. 2012; 23(2): 129-35. PubMed Abstract | Publisher Full Text

51. Del Rio D, Rodriguez-Mateos A, Spencer JP, et al: Dietary (poly)phenolics in human health: structures, bioavailability, and evidence of protective effects against chronic diseases. Antioxid Redox Signal. 2013; 18(14): 1818-92. PubMed Abstract | Publisher Full Text | Free Full Text

52. Horcajada MN, Sanchez C, Membrez Scalfo F, et al: Oleuropein or rutin consumption decreases the spontaneous development of osteoarthritis in the Hartley guinea pig. Osteoarthritis cartilage. 2015; 23(1): 94-102. PubMed Abstract | Publisher Full Text

53. Berbert $\mathrm{AA}$, Kondo $\mathrm{CR}$, Almendra $\mathrm{CL}$, et al: Supplementation of fish oil and olive oil in patients with rheumatoid arthritis. Nutrition. 2005; 21(2): 131-6. PubMed Abstract | Publisher Full Text

54. Omar SH: Oleuropein in olive and its pharmacological effects. Sci Pharm. 2010; 78(2): 133-54.

PubMed Abstract | Publisher Full Text | Free Full Text

55. Impellizzeri D, Esposito E, Mazzon E, et al:: Oleuropein aglycone, an olive oil compound, ameliorates development of arthritis caused by injection of collagen type II in mice. J Pharmacol Exp Ther. 2011; 339(3): 859-69. PubMed Abstract | Publisher Full Tex 
56. Puel C, Mathey J, Agalias A, et al.: Dose-response study of effect of oleuropein, an olive oil polyphenol, in an ovariectomy/inflammation experimental model of bone loss in the rat. Clin Nutr. 2006; 25(5): 859-68. PubMed Abstract | Publisher Full Text

57. Monti MC, Margarucci L, Tosco A, et al:: New insights on the interaction mechanism between tau protein and oleocanthal, an extra-virgin olive-oil bioactive component. Food Funct. 2011; 2(7): 423-8. PubMed Abstract | Publisher Full Text

58. Beauchamp GK, Keast RS, Morel D, et al.: Phytochemistry: ibuprofen-like activity in extra-virgin olive oil. Nature. 2005; 437(7055): 45-6. PubMed Abstract | Publisher Full Text

59. Hollman PC, van Trijp JM, Mengelers MJ, et al.: Bioavailability of the dietary antioxidant flavonol quercetin in man. Cancer Lett. 1997; 114(1-2): 139-40. PubMed Abstract | Publisher Full Text

60. Sakanashi $\mathrm{Y}$, Oyama K, Matsui $\mathrm{H}$, et al.: Possible use of quercetin, an antioxidant, for protection of cells suffering from overload of intracellular $\mathrm{Ca}^{2+}$ : a model experiment. Life Sci. 2008; 83(5-6): 164-9.

PubMed Abstract | Publisher Full Text

61. Nikniaz Z, Ostadrahimi A, Mahdavi R, et al:: Effects of Elaeagnus angustifolia L. supplementation on serum levels of inflammatory cytokines and matrix metalloproteinases in females with knee osteoarthritis. Complement Ther Med. 2014; 22(5): 864-9.

PubMed Abstract | Publisher Full Text
62.

Zhang FF, Driban JB, Lo GH, et al.: Vitamin D deficiency is associated with progression of knee osteoarthritis. J Nutr. 2014; 144(12): 2002-8. PubMed Abstract | Publisher Full Text | Free Full Text

63. Sanghi D, Mishra A, Sharma AC, et al.: Elucidation of dietary risk factors in osteoarthritis knee-a case-control study. J Am Coll Nutr. 2015; 34(1): 15-20.

PubMed Abstract | Publisher Full Text

64. Misra D, Booth SL, Tolstykh I, et al: Vitamin $\mathrm{K}$ deficiency is associated with incident knee osteoarthritis. Am J Med. 2013; 126(3): 243-8.

PubMed Abstract | Publisher Full Text | Free Full Text

65. Wilcox S, McClenaghan B, Sharpe PA, et al:: The steps to health randomized trial for arthritis: a self-directed exercise versus nutrition control program. Am J Prev Med. 2015; 48(1): 1-12.

PubMed Abstract | Publisher Full Text

66. Catalano $\mathrm{D}$, Trovato $\mathrm{GM}, \mathrm{Pace} \mathrm{P}$, et al:: Mediterranean diet and physical activity: an intervention study. Does olive oil exercise the body through the mind? Int J Cardiol. 2013; 168(4): 4408-9.

PubMed Abstract | Publisher Full Text

67. Kien CL, Bunn JY, Tompkins CL, et al.: Substituting dietary monounsaturated fat for saturated fat is associated with increased daily physical activity and resting energy expenditure and with changes in mood. Am J Clin Nutr. 2013; 97(4): 689-97.

PubMed Abstract | Publisher Full Text | Free Full Text 


\section{Open Peer Review}

\section{Current Peer Review Status: ? ?}

\section{Version 2}

Reviewer Report 29 December 2015

https://doi.org/10.5256/f1000research.6514.r11704

(C) 2015 Bastiaenen C. This is an open access peer review report distributed under the terms of the Creative Commons Attribution License, which permits unrestricted use, distribution, and reproduction in any medium, provided the original work is properly cited.

\section{Carolien H. G Bastiaenen}

Department of Epidemiology, Maastricht University, Maastricht, The Netherlands

It is an well-written and informative paper on the topic. The paper underlines the importance of physical expertise on the treatment of OA, combined with an appropriate diet in post-operative situations. Nevertheless I have serious comments on the scientific basis of the review.

The review is not performed in line with a scientific accepted methodology regarding systematic reviews. The search terms only are focused on the topic OA and not on methodological terms. There are no in-and exclusion criteria for the papers formulated. Also, there is no quality assessment of the papers regarding methodological quality or a systematically presented evidence synthesis. Therefore the presentation of the results, discussion and the conclusion is difficult to interpret.

Competing Interests: No competing interests were disclosed.

I confirm that I have read this submission and believe that I have an appropriate level of expertise to confirm that it is of an acceptable scientific standard, however I have significant reservations, as outlined above.

Author Response 30 Dec 2015

Giuseppe Musumeci, Human Anatomy and Histology Section, School of Medicine, University of Catania, Catania, Italy

Point by point replies

Reviewer

It is an well-written and informative paper on he topic. The paper underlines the importance of physical expertise on the treatment of OA, combined with an appropriate diet in postoperative situations. Nevertheless I have serious comments on the scientific basis of the 
review.

\section{Response}

The authors thank the reviewer for this comment.

Reviewer

The review is not performed in line with a scientific accepted methodology regarding systematic reviews. The search terms only are focused on the topic OA and not on methodological terms. There are no in-and exclusion criteria for the papers formulated. Also, there is no quality assessment of the papers regarding methodological quality or a systematically presented evidence synthesis. Therefore the presentation of the results, discussion and the conclusion is difficult to interpret.

Response

We thank the reviewer for this comment. Probably, the misunderstanding came from the scope of this paper. Authors intentions were to write a Narrative Review, as now specified in the methodological section, although this type of review has some limitations.

There are two kinds of review articles commonly present in the scientific literature as shown in the following editorial: Rother, ET: Systematic literature review $\mathrm{X}$ narrative review. Acta paul. enferm. 2007; 20(2): 5-6. Publisher Full Text.

In summary this editorial says:

Narrative literature review articles are contributions which describe and debate the state of scientific knowledge of a specific field with a critical analysis of the literature published. These types of review articles do not list the types of databases and methodological approaches used to carry out the review nor the evaluation criteria for inclusion of retrieved articles during databases search, anyway we added in the methodology section more information and details as kindly suggested (inclusion and exclusion criteria and so on) to improve our review and to help readers better understand.

Narrative literature review articles have a key role in continuous learning/training because they provide readers with update knowledge about a specific field of interest, although it does not describe the methodological approach that would permit reproduction of data nor answer to specific quantitative research questions. Results are of a qualitative rather then a quantitative meaning.

Moreover, systemic literature review "is a well planned review to answer specific research questions using a systematic and explicit methodology to identify, select, and critically evaluate results of the studies included in the literature review". Therefore, systematic literature review utilize methodological rigor to prevent the prejudice of a narrative review.

The Authors hope that the reviewer will be satisfied with the changes and revisions made.

Thank you for your time and for considering our paper.

Competing Interests: No competing interests were disclosed. 
Reviewer Report 07 May 2015

https://doi.org/10.5256/f1000research.6514.r8515

(c) 2015 Gadjanski I. This is an open access peer review report distributed under the terms of the Creative Commons Attribution License, which permits unrestricted use, distribution, and reproduction in any medium, provided the original work is properly cited.

\section{Ivana Gadjanski}

R\&D Center for Bioengineering - BioIRC, Kragujevac \& Metropolitan University Belgrade, Kragujevac, Serbia

The review article by Musumeci et al. under the title "Post-operative rehabilitation and nutrition in osteoarthritis" is well written, with appropriate title and abstract. The article largely accomplishes to underline importance of exercise, combined with an appropriate daily diet, in postoperative rehabilitation for osteoarthritis (OA) patients. However, I have several comments which I hope will help the authors to bring across this important message even more efficiently.

Major points:

It is not very clear how the selection of articles was performed. The authors state: "The literature search was conducted from in March 2014 to April 2015 on PubMed, Scopus, Web of Science and Google Scholar using appropriate keywords (osteoarthritis, rehabilitation, exercise and nutrition). Of approximately 160 papers (original articles, systematic and metaanalysis reviews) only 67 have been chosen and considered appropriate for the purpose of the review. The other papers, have not been considered as they resulted outside the scope of the research." However, out of these 67, only 7 are from 2014 and 3 from 2015. The rest range from 1995-2013 (References). The authors should clarify the selection criteria and perhaps include more of the more recent papers.

Suggestions of the papers to include:

OARSI Clinical Trials Recommendations: Design and conduct of clinical trials of lifestyle diet and exercise interventions for osteoarthritis

Knee osteoarthritis: Clinical connections to articular cartilage structure and function

Exercise for osteoarthritis of the knee

Regular Exercises in Knee and Hip Osteoarthritis

Exercise, nutrition and managing hip fracture in older persons

The authors state: "OA is a degenerative process involving the progressive loss of structural features and functionality of the articular cartilage caused by an imbalance between anabolic and catabolic processes in the cartilage tissue, so that cartilage degradation exceeds reparative processes and OA progresses" - this is not sufficiently precise, since the subchondral bone is also involved in pathogenesis of OA. The authors should also mention this and further on, comment on the effects of weight loss/gain and exercise training on bone mineral density in OA patients. 
Suggested paper: The independent and combined effects of intensive weight loss and exercise training on bone mineral density in overweight and obese older adults with osteoarthritis.

Minor points:

"Cartilage is a slow adapting tissue, indeed it undergoes 75\% adaptation in approximately 2 years." - Reference for this statement?

The paragraph under title "Second step post-operative rehabilitation in OA" - the whole paragraph is very repetitive, with the same kind of information provided in the table as well. Can be shortened.

It would be good to give short overview of the available surgical procedures to treat OA. The authors mention "Arthroscopic procedures, such as chondroplasty or microfracture, may resolve faster than osteochondral autograph transplantation (OATS) or autologous chondrocyte implantation (ACI) that involve larger incisions, requiring a slower exercise rehabilitation program", but it would be better if they gave a short description of each procedure (not more than a sentence long).

Competing Interests: No competing interests were disclosed.

\section{I confirm that I have read this submission and believe that I have an appropriate level of expertise to confirm that it is of an acceptable scientific standard, however I have significant reservations, as outlined above.}

Author Response 08 Jun 2015

Giuseppe Musumeci, Human Anatomy and Histology Section, School of Medicine, University of Catania, Catania, Italy

Thank you for your review and for the comments. Comments from reviewers are all valuable and very helpful for revising and improving our paper. We have studied the comments carefully and have made corrections which we hope meet with your approval.

\section{Point by point replies}

Reviewer: It is not very clear how the selection of articles was performed. The authors state: "The literature search was conducted from in March 2014 to April 2015 on PubMed, Scopus, Web of Science and Google Scholar using appropriate keywords (osteoarthritis, rehabilitation, exercise and nutrition). Of approximately 160 papers (original articles, systematic and meta-analysis reviews) only 67 have been chosen and considered appropriate for the purpose of the review. The other papers, have not been considered as they resulted outside the scope of the research." However, out of these 67, only 7 are from 2014 and 3 from 2015. The rest range from 1995-2013 (References). The authors should clarify the selection criteria and perhaps include more of the more recent papers.

Response: The authors thank the reviewer for this comment. Perhaps we have not been clear, we meant to say that we have made the literature search in the period 
March 2014 - April 2015, but the period considered in the selection of the references is much larger (1995 - 2015). Thank you for letting us know about the possible misinterpretation. We have corrected the text to be clearer. Thank you for the papers suggested, we included most of them in the text.

Reviewer: The authors state: "OA is a degenerative process involving the progressive loss of structural features and functionality of the articular cartilage caused by an imbalance between anabolic and catabolic processes in the cartilage tissue, so that cartilage degradation exceeds reparative processes and OA progresses" - this is not sufficiently precise, since the subchondral bone is also involved in pathogenesis of $\mathrm{OA}$. The authors should also mention this and further on, comment on the effects of weight loss/gain and exercise training on bone mineral density in OA patients.

Response: We have provided to modify the text with comment on the involvement of the subchondral bone in pathogenesis of $\mathrm{OA}$, and on the effects of weight loss/gain and exercise training on bone mineral density in OA patients. Thank you for the paper suggestion.

Reviewer: "Cartilage is a slow adapting tissue, indeed it undergoes $75 \%$ adaptation in approximately 2 years." - Reference for this statement?

Response: We inserted the following reference: Hambly K, Griva K: IKDC or KOOS? Which measures symptoms and disabilities most important to postoperative articular cartilage repair patients? Am J Sports Med. 2008;36(9):1695-704.

Reviewer: The paragraph under title "Second step post-operative rehabilitation in $\mathrm{OA}^{\prime \prime}$ - the whole paragraph is very repetitive, with the same kind of information provided in the table as well. Can be shortened.

Response: We have provided for modifying the text and making it shorter.

Reviewer: It would be good to give short overview of the available surgical procedures to treat OA. The authors mention "Arthroscopic procedures, such as chondroplasty or microfracture, may resolve faster than osteochondral autograph transplantation (OATS) or autologous chondrocyte implantation (ACI) that involve larger incisions, requiring a slower exercise rehabilitation program", but it would be better if they gave a short description of each procedure (not more than a sentence long).

Response: We have provided for modifying the text with a short description of each procedure.

The Authors hope that the reviewer will be satisfied with the changes and revisions made. Thank you for your time and for considering our paper.

Competing Interests: None of the authors have any conflict of interest to declare. 
Author Response 30 Dec 2015

Giuseppe Musumeci, Human Anatomy and Histology Section, School of Medicine, University of Catania, Catania, Italy

Thank you for your review and for the comments. Comments from reviewers are all valuable and very helpful for revising and improving our paper. We have studied the comments carefully and have made corrections which we hope meet with your approval.

\section{Point by point replies}

\section{Reviewer}

It is not very clear how the selection of articles was performed. The authors state: "The literature search was conducted from in March 2014 to April 2015 on PubMed, Scopus, Web of Science and Google Scholar using appropriate keywords (osteoarthritis, rehabilitation, exercise and nutrition). Of approximately 160 papers (original articles, systematic and metaanalysis reviews) only 67 have been chosen and considered appropriate for the purpose of the review. The other papers, have not been considered as they resulted outside the scope of the research." However, out of these 67, only 7 are from 2014 and 3 from 2015. The rest range from 1995-2013 (References). The authors should clarify the selection criteria and perhaps include more of the more recent papers.

\section{Response}

The authors thank the reviewer for this comment. Perhaps we have not been clear, we meant to say that we have made the literature search in the period March 2014 - December 2015 , but the period considered in the selection of the references is much larger (1995 2015). Thank you for letting us know about the possible misinterpretation. We have corrected the text to be clearer. Thank you for the papers suggested, we included most of them in the text.

\section{Reviewer}

The authors state: "OA is a degenerative process involving the progressive loss of structural features and functionality of the articular cartilage caused by an imbalance between anabolic and catabolic processes in the cartilage tissue, so that cartilage degradation exceeds reparative processes and OA progresses" - this is not sufficiently precise, since the subchondral bone is also involved in pathogenesis of OA. The authors should also mention this and further on, comment on the effects of weight loss/gain and exercise training on bone mineral density in OA patients.

\section{Response}

We have provided to modify the text with comment on the involvement of the subchondral bone in pathogenesis of $\mathrm{OA}$, and on the effects of weight loss/gain and exercise training on bone mineral density in OA patients. Thank you for the paper suggestion.

Reviewer

"Cartilage is a slow adapting tissue, indeed it undergoes 75\% adaptation in approximately 2 years." - Reference for this statement? 


\section{Response}

We inserted the following reference: Hambly K, Griva K: IKDC or KOOS? Which measures symptoms and disabilities most important to postoperative articular cartilage repair patients? Am J Sports Med. 2008;36(9):1695-704.

Reviewer

The paragraph under title "Second step post-operative rehabilitation in OA" - the whole paragraph is very repetitive, with the same kind of information provided in the table as well. Can be shortened.

Response

We have provided for modifying the text and making it shorter.

Reviewer

It would be good to give short overview of the available surgical procedures to treat OA. The authors mention "Arthroscopic procedures, such as chondroplasty or microfracture, may resolve faster than osteochondral autograph transplantation (OATS) or autologous chondrocyte implantation (ACI) that involve larger incisions, requiring a slower exercise rehabilitation program", but it would be better if they gave a short description of each procedure (not more than a sentence long).

Response

We have provided for modifying the text with a short description of each procedure.

The Authors hope that the reviewer will be satisfied with the changes and revisions made.

Thank you for your time and for considering our paper.

Competing Interests: No competing interests were disclosed. 
The benefits of publishing with F1000Research:

- Your article is published within days, with no editorial bias

- You can publish traditional articles, null/negative results, case reports, data notes and more

- The peer review process is transparent and collaborative

- Your article is indexed in PubMed after passing peer review

- Dedicated customer support at every stage

For pre-submission enquiries, contact research@f1000.com 